\title{
ANALISA BIOMEKANIKA KERJA DAN LINGKUNGAN FISIK KERJA TERHADAP KEPUASAN KERJA PEGAWAI
}

\author{
Andry Septianto, ST., M.M \\ Dosen Fakultas Teknik Prodi Teknik Industri Universitas Pamulang \\ Dosen01303@unpam.ac.id
}

\begin{abstract}
ABSTRAK
Tujuan dari penelitian ini adalah untuk menganalisis postur kerja pegawai dan lingkungan kerja fisik diruang kerja agar menjadi ergonomi yang dimana pegawai bisa meminimalisir gangguan musculoskeletal disorder dan gangguan lainnya sehingga pegawai dapat memperoleh kepuasan kerja saat melakukan aktivitas kerja di MTS Ma'arif Cipakem. Metode yang dipakai adalah metode deskripitf.dengan menggunakan pendekatan kualitatif yang dikuantitatifkan. Dikarenakan hasil akhirnya berupa angka dan dimasukkan ke dalam kategori tersebut, maka disebut pendekatan kualitatif yang dikuantitatifkan. Berdasarkan hasil analisis biomekanika kerja dengan metode Rapid Entire Body Assessment (REBA) yang menghasilkan skor sebesar 10 sehingga postur kerja pegawai termasuk dalam kategori level risiko tinggi. Kemudian, lingkungan kerja fisik dianalisis dengan menggunakan alat lux meter untuk menentukan tingkat pencahayaan dimana diperoleh nilai sebesar 82.3 lux dan alat sound level meter untuk tingkat kebisingan dimana diperoleh nilai 102 desibel. Selanjutnya, kepuasan kerja dianalisis dengan menggunakan metode ekspresi wajah (face scale) yang menghasilkan tingkat kepuasan kerja pegawai adalah $66 \%$ sehingga dapat disimpulkan bahwa pegawai di MTS Ma'arif Cipakem merasakan rasa gembira dalam melakukan aktivitas kerjanya, meskipun perlu perbaikan baik dari postur kerja maupun lingkungan kerja pegawai.
\end{abstract}

Kata Kunci: Biomekanika Kerja, Lingkungan Kerja Fisik, Kepuasan Kerja

\section{PENDAHULUAN}

Pengetahuan tentang biomekanika sangat diperlukan untuk mengetahui mekanisme terjadinya kecelakaan kerja, sehingga pendekatan yang efektif dan ilmiah dapat membantu manusia bekerja dengan aman. Salah satu faktor dalam biomekanika kerja adalah postur dan sikap tubuh pada saat melakukan aktivitas tersebut. Masalah postur kerja sangatlah penting untuk diperhatikan, karena langsung berhubungan ke proses kerja itu sendiri. Berdasarkan data dari Departemen Kesehatan dapat diketahui bahwa dari semua penyakit akibat kerja yang terjadi di setiap perusahaan di Indonesia cedera muskuloskeletal adalah penyakit yang menduduki posisi paling rentan diantara penyakit akibat kerja lainnya dengan persentase sebesar $16 \%$. Kondisi kerja di dalam sekolah merupakan faktor yang cukup penting dalam pelaksanaan proses kerja. Yang dimaksud dengan kondisi kerja adalah lingkungan kerja fisik yang dapat dipersiapkan oleh manajemen yang bersangkutan pada sekolah tersebut. Berdasarkan hasil penelitian sebelumnya di Semarang bahwa kontribusi lingkungan kerja sebesar $16.7 \%$ terhadap kepuasan pegawai. Oleh sebab itu, kondisi kerja yang terdiri dari faktorfaktor seperti kondisi fisik, kondisi psikologis, dan kondisi sementara dari lingkungan kerja harus diperhatikan agar para pegawai dapat merasa nyaman dalam bekerja sehingga dapat memperoleh kepuasan kerja. Dengan demikian, terlihat bahwa faktor biomekanika kerja dan lingkungan fisik kerja mempelajari bagaimana untuk meningkatkan kesejahteraan fisik dan mental melalui upaya pencegahan 
cedera akibat postur kerja yang salah dan penyakit akibat kerja serta menurunkan beban kerja fisik dan mental sehingga sikap pegawai yang efektif dapat menimbulkan kepuasan kerja.

\section{A. Tujuan Penelitian}

Menentukan tujuan merupakan langkah awal dalam penyusunan suatu laporan penelitian agar penelitian dapat berjalan dengan terencana dan searah. Adapun tujuan dari penelitian ini, yaitu:

1. Untuk menganalisa postur kerja pegawai agar menjadi ergonomis yang dimana pegawai dapat meminimalisir gangguan musculoskeletal disorders dan gangguan lainnya sehingga pegawai dapat memperoleh kepuasan kerja.

2. Untuk menganalisis tingkat pencahayaan dan tingkat kebisingan di dalam ruang kerja agar lingkungan kerja menjadi ergonomis yang dimana pegawai dapat meminimalisir gangguan musculoskeletal disorders dan gangguan lainnya sehingga pegawai dapat memperoleh kepuasan kerja.

3. Untuk mengetahui tingkat kepuasan kerja pegawai saat melakukan aktivitas kerja di ruang kerja.

\section{DASAR TEORI}

Biomekanika merupakan studi tentang karakteristik-karakteristik tubuh manusia dalam istilah mekanik. Biomekanika dioperasikan pada tubuh manusia baik saat tubuh dalam keadaan statis ataupun dalam keadaan dinamis. Oleh karena itu, harus memperhatikan biomekanika sehingga sistem kerja menjadi ergonomis. Dalam analisis biomekanika, tubuh manusia dipandang sebagai sistem yang terdiri dari link (penghubung) dan joint (sambungan), tiap link mewakili segmen-segmen tubuh tertentu dan tiap joint menggambarkan sendi yang ada. Postur kerja merupakan pengaturan sikap tubuh saat bekerja. Sikap kerja yang berbeda akan menghasilkan kekuatan yang berbeda pula. Pada saat bekerja sebaiknya postur dilakukan secara alamiah sehingga dapat meminimalisasi timbulnya cidera muscoluskeletal. Kenyamanan tercipta bila pegawai telah melakukan postur kerja yang baik dan aman. Lingkungan kerja fisik dapat dibagi dalam dua kategori, yakni lingkungan yang langsung berhubungan dengan pegawai, seperti pusat kerja, kursi, meja, dan sebagainya. Sedangkan, lingkungan perantara atau lingkungan umum dapat juga disebut lingkungan kerja yang mempengaruhi kondisi manusia. Misalnya, temperatur, kelembaban, sirkulasi udara, pencahayaan, kebisingan, getaran mekanis, bau tidak sedap, warna, dan lain-lain. Pengertian kondisi kerja menurut (Afrianti, 2012) yang dikutip dari buku Anwar Prabu Mangkunegara (2005:105) adalah semua aspek fisik kerja, psikologis kerja dan peraturan kerja yang dapat mempengaruhi kepuasan kerja dan pencapaian produktivitas kerja. Menurut (Kurnia, 2013) mengatakan bahwa salah satu dari ukuran kepuasan kerja yang banyak dipergunakan secara luas adalah metode Face Scale yang dikembangkan oleh Kunin pada pertengahan tahun 1950 -an. Face scale ini terdiri dari serangkaian atau sekumpulan wajah-wajah dengan berbagai ekspresi emosi yang berbedabeda. Responden diminta untuk dapat menunjukkan dari lima ekspresi wajah yang tersedia ekspresi wajah manakah yang paling mewakili perasaan mereka kepada kepuasan secara keseluruhan terhadap pekerjaan mereka. Keuntungan utama dari face scale ini adalah kesimpelannya dan responden tidak perlu melalui sebuah jenjang membaca yang tinggi untuk dapat menyelesaikannya. Sementara, kerugian potensial dari face scale ini adalah ia tidak menyediakan informasi mengenai kepuasan pegawai dengan aspek yang berbeda dari pekerjaan mereka. 


\section{METODE DAN TEKNIK PENGUKURAN}

Penelitian bertempat di Sekolah Madrasah (MTs) Ma'arif NU Cipakem yang terletak di Jalan Raya Desa Cipakem, Kecamatan Maleber, Kabupaten Kuningan, Jawa Barat. Penelitian ini mulai dilakukan pada bulan November 2016 pada pegawai Sekolah Madrasah (MTs) Ma'arif NU Cipakem. Objek penelitian adalah postur tubuh pegawai pada saat melakukan aktivitas, lingkungan fisik kerja pegawai yang terdiri dari kebisingan suara dan pencahayaan ruang kerja pegawai, dan ekspresi wajah pegawai pada saat melakukan aktivitas pekerjaan. Metode yang dipakai dalam melakukan penelitian pada pegawai Sekolah Madrasah (MTs) Ma'arif NU Cipakem yang terletak di Jalan Raya Desa Cipakem, Kecamatan Maleber, Kabupaten Kuningan, Jawa Barat adalah metode deskripitf dengan menggunakan pendekatan kualitatif yang dikuantitatifkan. Pendekatan kualitatif dalam penelitian ini adalah data yang diwujudkan dalam kata keadaan atau kata sifat. Dikarenakan hasil akhirnya berupa angka dan dimasukkan ke dalam kategori tersebut, maka disebut pendekatan kualitatif yang dikuantitatifkan. Adapun metode pendukung penelitian yang digunakan adalah sebagai berikut:

\section{Metode Deskriptif}

\section{Metode}

ini

menggambarkan data masalah yang ada dan berkembang pada saat penelitian dilakukan dengan cara melihat keadaan serta mengumpulkan beberapa data berdasarkan fakta-fakta yang ada di sekolah.

\section{Metode Kasus Atau Lapangan}

$\begin{array}{lrr}\text { Penelitian ini } & \text { bersifat } \\ \text { mendalam yang hasilnya } \\ \text { merupakan gambaran yang } \\ \text { lengkap dan terorganisir. Metode } \\ \text { ini bertujuan untuk mempelajari } \\ \text { tentang latar belakang, status saat }\end{array}$

ini, dan interaksi lingkungan suatu pegawai pada Sekolah Madrasah (MTs) Ma'arif NU Cipakem yang terletak di Jalan Raya Desa Cipakem, Kecamatan Maleber, Kabupaten Kuningan, Jawa Barat.

\section{Metode Historis}

Metode ini bertujuan untuk mengumpulkan data sekolah baik data sekolah pada masa kini maupun data sekolah pada masa lalu. Lalu, data sekolah tersebut dipakai untuk melihat perkembangan sekolah.

Kerangka berpikir dalam penelitian ini akan ditunjukkan pada Gambar 3.1, yaitu:

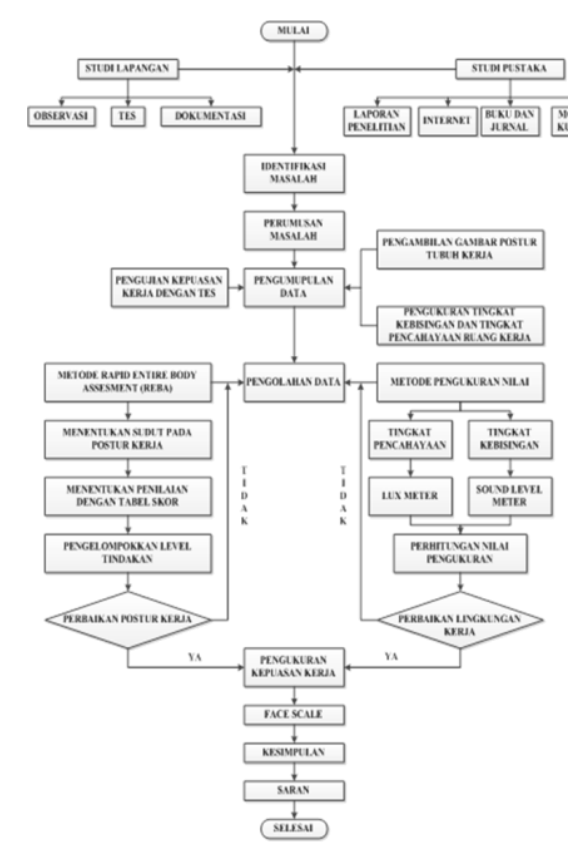

Gambar 3.1 Kerangka Berpikir Penelitian (Sumber: Pengolahan Sendiri)

\section{IV.HASIL DAN PEMBAHASAN}

Berikut ini adalah hasil postur kerja yang diperoleh berupa pengambilan foto pegawai tata usaha di MTS Ma'arif Cipakem yang sedang melakukan aktivitas kerja dan akan ditunjukkan pada Gambar 4.2, yaitu: 


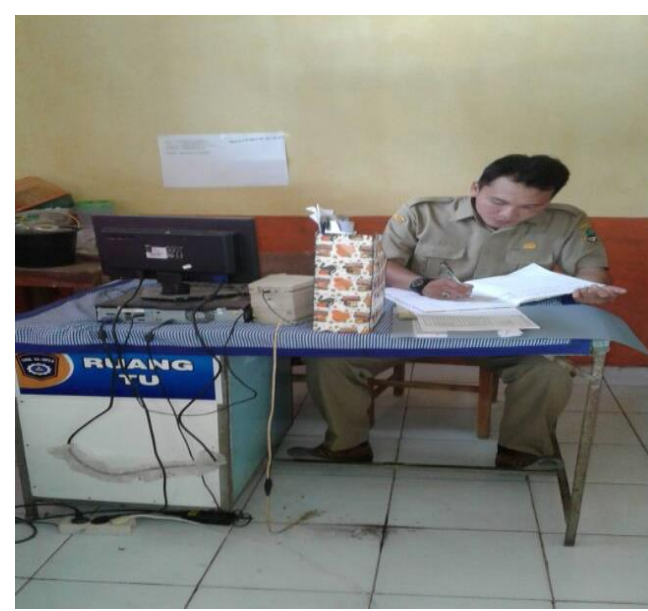

Gambar 4.2 Postur Kerja (Sumber: MTS Ma'arif Cipakem)

Berikut ini adalah tahapan pemberian skor dengan metode Rapid Entire Body Assessment (REBA) dapat ditunjukkan pada Gambar 4.3, yaitu:

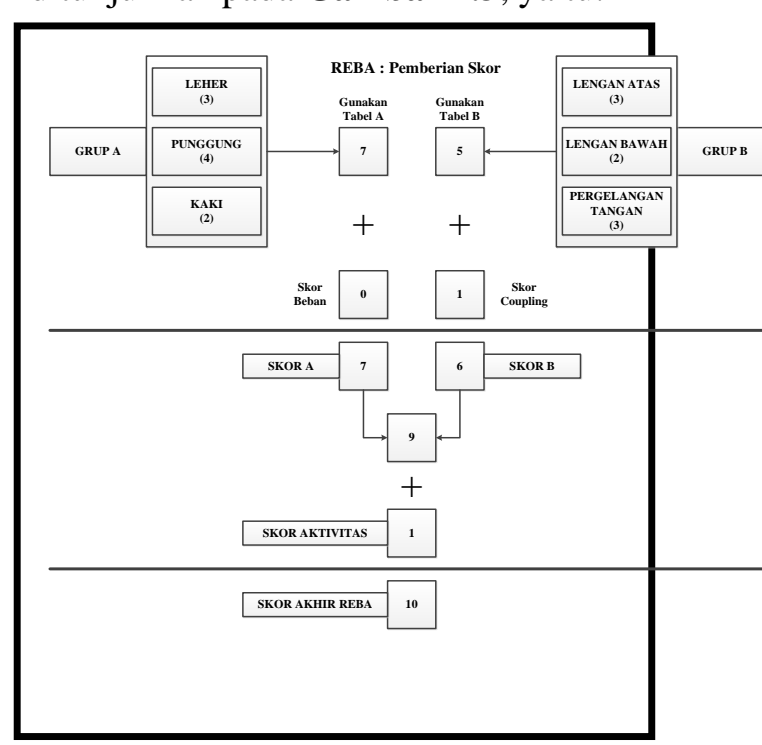

Gambar 4.3 Pemberian Skor REBA (Sumber: Pengolahan Sendiri)

Berdasarkan hasil postur tubuh tersebut bahwa pemberian skor pada postur kerja leher bahwa pergerakan leher postur tersebut lebih dari $20^{\circ}$ sehingga diberi skor 2 dan dikarenakan terjadi perubahan skor yang diakibatkan dari postur leher yang miring ke samping, maka ditambah skor 1 . Oleh karena itu, skor postur kerja leher adalah 3. Berdasarkan hasil postur tubuh tersebut bahwa pemberian skor pada postur kerja punggung bahwa pergerakan punggung postur tersebut berada diantara sudut $20^{\circ}-60^{\circ}$ sehingga diberi skor 3 dan dikarenakan terjadi perubahan skor yang diakibatkan dari postur punggung yang miring ke samping, maka ditambah skor 1 . Oleh karena itu, skor postur kerja punggung adalah 4. Berdasarkan hasil postur tubuh tersebut bahwa pemberian skor pada postur kerja kaki bahwa pergerakan kaki postur tersebut adalah (kaki tertopang, bobot tersebar merata, jalan atau duduk) sehingga diberi skor 1 dan dikarenakan terjadi perubahan skor yang diakibatkan dari postur kaki yang dimana lututnya antara sudut $30^{\circ}-60^{\circ}$, maka ditambah skor 1. Oleh karena itu, skor postur kerja kaki adalah 2 . Berdasarkan hasil skor postur tubuh tersebut, yaitu postur tubuh leher diberi skor 3, postur tubuh punggung diberi skor 4, dan postur tubuh kaki diberi skor 2, maka skor tersebut di analisis dengan menggunakan Tabel Skor A sehingga skor A postur kerja adalah 7 . Berdasarkan data postur kerja tersebut bahwa beban yang digunakan pada saat aktivitas kerja adalah kurang dari $5 \mathrm{~kg}$ yakni perlengkapan alat tulis kantor, maka skor beban REBA yang diperoleh bernilai nol (0).

Berdasarkan hasil postur tubuh tersebut bahwa pemberian skor pada postur kerja lengan atas bahwa pergerakan lengan atas postur tersebut lebih dari $20^{\circ}$ sehingga diberi skor 2 dan dikarenakan terjadi perubahan skor yang diakibatkan dari postur lengan atas yang bahunya ditinggikan, maka ditambah skor 1. Oleh karena itu, skor postur kerja lengan atas adalah 3. Berdasarkan hasil postur tubuh tersebut bahwa pemberian skor pada postur kerja lengan bawah bahwa pergerakan lengan bawah postur tersebut kurang dari $20^{\circ}$ sehingga diberi skor 2. Oleh karena itu, skor postur kerja lengan bawah adalah 2. Berdasarkan hasil postur tubuh tersebut bahwa pemberian skor pada postur kerja pergelangan tangan bahwa pergerakan pergelangan tanga postur tersebut lebih dari $15^{\circ}$ sehingga diberi skor 2 dan dikarenakan terjadi perubahan skor yang diakibatkan dari postur pergelangan tangan yang menyimpang dari samping 
tubuh, maka ditambah skor 1. Oleh karena itu, skor postur kerja pergelangan tangan adalah 3. Berdasarkan hasil skor postur tubuh tersebut, yaitu postur tubuh lengan atas diberi skor 3, postur tubuh lengan bawah diberi skor 2, dan postur tubuh pergelangan tangan diberi skor 3 , maka skor tersebut di analisis dengan menggunakan Tabel Skor B sehingga skor B postur kerja adalah 5 . Berdasarkan data postur kerja tersebut bahwa pegangan yang digunakan pada saat aktivitas kerja adalah kategori fair dimana pegangan tangan bisa diterima tapi tidak ideal atau coupling lebih sesuai digunakan oleh bagian lain dari tubuh, maka skor beban REBA yang diperoleh bernilai satu (1).

Berdasarkan hasil skor postur tubuh tersebut, yaitu skor A postur tubuh diperoleh skor 7 dan skor postur tubuh B diperoleh skor 5, maka skor tersebut di analisis dengan menggunakan Tabel Skor C sehingga skor C postur kerja adalah 9. Setelah ditambahkan dengan skor aktivitas REBA, maka diperoleh skor akhir REBA dengan nilai 10. Selanjutnya, untuk mengetahui risiko postur kerja dapat dilihat dalam tabel skor risiko REBA. Apabila skor yang didapat dari Tabel $\mathrm{C}$ sebesar 1 maka action level terletak pada tingkatan 0 sehingga level risiko yang diperoleh bisa diabaikan dan tidak perlu tindakan perbaikan. Lalu, apabila skor yang didapat dari Tabel C sebesar 2-3, maka action level terletak pada tingkatan 1 sehingga level risiko yang diperoleh rendah dan mungkin perlu dilakukan tindakan perbaikan. Kemudian, apabila skor yang didapat dari Tabel $\mathrm{C}$ sebesar 4-7, maka action level terletak pada tingkatan 2 sehingga level risiko yang diperoleh sedang dan perlu dilakukan tindakan perbaikan. Selanjutnya, apabila skor yang didapat dari Tabel $\mathrm{C}$ sebesar 8-10, maka action level terletak pada tingkatan 3 sehingga level risiko yang diperoleh tinggi dan perlu segera dilakukan tindakan perbaikan.

Lalu, apabila skor yang didapat dari Tabel C sebesar 11-15, maka action level terletak pada tingkatan 4 sehingga level risiko yang diperoleh sangat tinggi dan perlu saat ini juga dilakukan tindakan perbaikan. Berdasarkan hasil skor akhir Rapid Entire Body Assessment (REBA) yang diperoleh sebesar 10, tabel risiko Rapid Entire Body Assessment (REBA) menunjukkan kondisi ini berada pada level risiko yang tinggi, maka perlu segera tindakan untuk memperbaiki postur kerja pada pegawai MTS Ma'arif Cipakem. Oleh karena itu, perbaikan dapat dilakukan dengan merubah bagian perubahan pada sikap duduk sehingga dapat mengurangi gejala musculoskeletal disorders saat sedang melakukan aktivitas kerja. Aktivitas kerja yang dilakukan sebaiknya pada postur normal.

Diketahui data dimensi ruang kerja tersebut memiliki ukuran panjang ruang kerja adalah 9 meter, lebar ruang kerja adalah 6 meter, dan tinggi ruang kerja adalah 3 meter. Kemudian, diketahui data lampu yang digunakan dengan melihat catalog lampu adalah lampu neon bermerek Phillips yang memiiki daya listrik sebesar 23 Watt dan waktu operasi selama 8.000 jam dengan lumen sebesar $54 \mathrm{Lm} / \mathrm{w}$. Berdasarkan daya listrik lampu neon sebesar 23 Watt, maka tingkat efisiensi sebesar $70 \%$. Sedangkan, tingkat utilisasi ruangan selama satu semester atau enam bulan sebesar 54\% yang diperoleh dari perhitungan berikut ini, yaitu:

$$
\begin{aligned}
& \text { Waktu pemakaian lampu }=6 \\
& \text { bulan } x 30 \text { hari }=180 \text { hari }
\end{aligned}
$$

$$
\begin{aligned}
& \begin{array}{c}
180 \\
\text { hari } x \\
24 \text { jam } \\
=4320 \\
\text { jam }
\end{array} \\
& \text { Utilisasi }(\eta \mathrm{R})=\frac{4320 \mathrm{Jam}}{8000 \mathrm{Jam}} \mathrm{x} \\
& 100 \%=54 \%
\end{aligned}
$$

Selanjutnya, hasil dari data pengamatan tingkat pencahayaan tersebut dapat dilakukan perhitungan jumlah lampu yang dibutuhkan untuk ruang kerja di MTS Ma'arif Cipakem 
sehingga bisa mengetahui jumlah lampu yang dibutuhkan agar tingkat pencahayaan sesuai dengan standar yang telah ditetapkan. Berikut ini merupakan hasil perhitungan jumlah titik lampu pada ruang kerja MTS Ma'arif Cipakem, yakni:

\section{a. Menghitung Intensitas Ruangan} Berdasarkan hasil pengamatan dari pengukuran pencahayaan dengan alat lux meter, maka diperoleh nilai sebesar 2469 lux. Setelah diketahui jumlah total tingkat pencahayaan tersebut, maka dilakukan perhitungan intensitas cahaya dengan menggunakan rumus:

$$
€=\frac{2469}{30}=82.3 \mathrm{Lux}
$$

Berdasarkan perhitungan tersebut, maka diperoleh hasil intensitas ruang kerja tersebut adalah 82.3 Lux.

\section{b. Menghitung Flux Cahaya}

Berdasarkan data yang diperoleh dari catalog lampu neon 23 Watt tersebut yang memiliki $54 \mathrm{Lm} / \mathrm{w}$, maka flux cahaya tersebut dapat dihitung dengan menggunakan rumus sebagai berikut:

$$
\begin{aligned}
\varnothing & =23 \text { Watt } x 54 \\
\mathrm{Lm} / \mathrm{W} & =1242 \text { Lumen }
\end{aligned}
$$

Berdasarkan perhitungan tersebut, bahwa nilai flux cahaya yang diperoleh adalah 1242 lumen.

\section{c. Menghitung Faktor Ruangan}

Berdasarkan data yang diperoleh pada saat melakukan pengukuran, maka faktor ruangan tersebut dapat dihitung dengan menggunakan rumus:

$$
\begin{aligned}
& K=\frac{(9 \times 6)}{((3-0,85) \times(9+6))}= \\
& \frac{54}{((2.15) \times(15))}=\frac{54}{32.25}=1.67
\end{aligned}
$$

Meter
Berdasarkan perhitungan tersebut, bahwa nilai faktor ruangan $(\mathrm{K})$ yang diperoleh adalah 1.67 meter.

\section{d. Menghitung Jumah Titik Lampu}

Berdasarkan data yang telah diketahui dalam pengukuran tingkat pencahayaan tersebut, maka perhitungan jumlah titik lampu dapat digunakan dengan rumus sebagai berikut:

$$
\mathrm{N}=\frac{(1.25 \times 82.3 \times 9 \times 6)}{((1.67)(1242) \times 70 \% \times 54 \%)}=
$$

$$
=7.09 \text { titik lampu = } 7 \text { titik }
$$$$
\text { lampu (dibulatkan) }
$$

Berdasarkan perhitungan titik lampu bahwa ruang kerja di MTS Ma'arif Cipakem dengan ukuran panjang sebesar 9 meter, lebar 6 meter, dan 3 meter yang akan dipasang lampu neon dengan daya listrik sebesar 23 Watt memerlukan 7 titik lampu. Apabila dilakukan pemasangan lampu sebanyak 7 buah lampu neon yang memiliki daya listrik 23 Watt dengan $54 \mathrm{Lm} / \mathrm{w}$, maka ruang kerja di MTS Ma'arif Cipakem tersebut telah memenuhi standar yang sebagaimana telah ditetapkan berdasarkan KEPMENKES RI. No. 1405/MENKES/SK/XI/02. Setelah dilakukan pengukuran dengan lux meter, maka diperoleh nilai intensitas cahaya sebesar 325 Lux sehingga pencahayaan diruang kerja tersebut tidak membahayakan penglihatan pegawai yang sedang melakukan aktivitas kerja. Berdasarkan perhitungan rata-rata kebisingan suara dengan alat sound level meter diperoleh hasil sebesar 507275401401.40, yang selanjutnya dapat dihitung tingkat kebisingan suara sebagai berikut

$$
\begin{aligned}
& \text { Lek }=10 \quad \log (0.033 \quad \mathrm{x} \\
& \begin{array}{l}
(507275401401.40) \\
=10 \log (16740088246)
\end{array} \\
& =10 \times(10.22)=102.2 \text { desibel }(\mathrm{dB}) \\
& \text { Berdasarkan }
\end{aligned}
$$


di MTS Ma'arif Cipakem diperoleh nilai sebesar 102.2 desibel (dB) yang berarti bahwa ruang kerja tersebut berada pada zona $\mathrm{D}$ sehingga pegawai yang bekerja perlu memakai earplug agar bisa meminimalisir gangguan pendengaran pada telinga. Namun, berdasarkan keputusan Menteri Tenaga Kerja No. KEP/51/MEN/1999 bahwa ruang kerja tersebut berada pada zona dengan pelindung ear muff karena ruang kerja di MTS Ma'arif Cipakem memiliki intensitas kebisingan lebih besar dari 95 dBA. Adapun aspek-aspek kepuasan kerja yang dilihat dari sisi biomekanika kerja dan lingkungan kerja fisik akan ditunjukkan dalam Tabel 4.21 sebagai berikut:

Tabel 4.21 Aspek Kepuasan Kerja Dengan Skala Penilaian Ekspresi Wajah

\begin{tabular}{|c|c|c|c|c|c|c|}
\hline \multirow{2}{*}{\multicolumn{2}{|c|}{ Aspek Kepuasan Kerja }} & \multicolumn{5}{|c|}{$\begin{array}{l}\text { Skala Penilaian Ekspresi } \\
\text { Wajah }\end{array}$} \\
\hline & & SG & G & $\mathrm{N}$ & C & $\mathrm{SC}$ \\
\hline & $\begin{array}{l}\text { Bagaimana perasaan Anda saat berada di kursi } \\
\text { duduk pada tempat kerja Anda. }\end{array}$ & & & & & \\
\hline 2. & $\begin{array}{l}\text { Bagaimana perasaan Anda setelah memasuki ruang } \\
\text { kerja dengan sistem pencahayaan yang ada di ruang } \\
\text { kerja Anda. }\end{array}$ & & & & & \\
\hline 3. & $\begin{array}{l}\text { Bagaimana perasaan Anda saat mengalami } \\
\text { gangguan-gangguan suara pada saat melakukan } \\
\text { akitivitas di tempat kerja Anda. }\end{array}$ & & & & & \\
\hline 4. & $\begin{array}{l}\text { Bagaimana perasaan Anda saat menyelesaikan } \\
\text { pekerjaan yang Anda lakukan di tempat kerja } \\
\text { Anda. }\end{array}$ & & & & & \\
\hline
\end{tabular}

Keterangan:

$\mathrm{SG}=$ Sangat Gembira $($ Skor $=5)$.

$\mathrm{G}=$ Gembira $($ Skor $=4)$.

$\mathrm{N}=\operatorname{Netral}($ Skor $=3)$.

$\mathrm{C}=$ Cemberut $($ Skor $=2)$.

$\mathrm{SC}=$ Sangat Cemberut $($ Skor $=1)$.

Selanjutnya, instrumen tersebut dijadikan sebuah angket dan disebarkan ke 44 pegawai yang bekerja di MTS Ma'arif Cipakem. Kemudian, data hasil pengumpulan penilaian aspek kepuasan kerja tersebut direkapitulasi berdasarkan skala ekspresi wajah (face scale) dari jawaban responden. Adapun hasil rekapitulasi data jawaban responden yang akan ditunjukkan dalam Tabel $\mathbf{4 . 2 3}$ sebagai berikut:

Tabel 4.23 Hasil Rekapitulasi Data Jawaban Responden

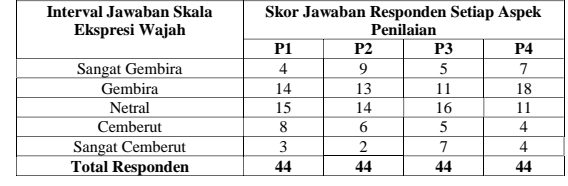

(Sumber: Pengolahan Sendiri)

Berdasarkan rekapitulasi data jawaban responden, maka dapat dilakukan perhitungan total skor dari tiap aspek penilaian ekspresi wajah (face scale). Menurut (Abduh, 2015), bahwa total skor dapat dihitung dengan menggunakan rumus sebagai berikut ini, yaitu:

\section{Total Skor $=\mathbf{T} \times$ Pn}

Dimana:

$\mathrm{T}$ : Total Jumlah Responden Yang Memilih.

Pn : Pilihan Angka Skor Skala Ekspresi Wajah.

Kemudian, melakukan interpretasi skor perhitungan dari aspek penilaian kepuasan pegawai dalam menyelesaikan pekerjaan. Menurut (Abduh, 2015), bahwa untuk mendapatkan hasil interpretasi skor, maka harus diketahui terlebih dahulu skor tertinggi (X) dan angka terendah $(\mathrm{Y})$ untuk item penilaian dengan rumus sebagai berikut:

\section{$\mathbf{Y}=$ Skor Tertinggi $\mathbf{x}$ Jumlah Responden. \\ $\mathbf{X}=$ Skor Terendah $\mathbf{x}$ Jumlah Responden.}

Menurut (Abduh, 2015), berikut ini merupakan rumus untuk menghitung interpretasi persen dengan menggunakan metode Interval skor persen (I), yakni: $I=\frac{100}{\text { Jumlah Item Skor Yang Digunakan }}$

Telah diketahui bahwa item skor yang digunakan dalam penelitian ini dengan menggunakan skala ekspresi wajah (face scale) adalah 5, maka interval skor persen, yakni:

$$
\mathrm{I}=\frac{\mathbf{1 0 0}}{\mathbf{5}}=\mathbf{2 0}
$$

Berdasarkan perhitungan interval persen tersebut, maka kriteria interpretasi skor adalah sebagai berikut ini, yaitu: 


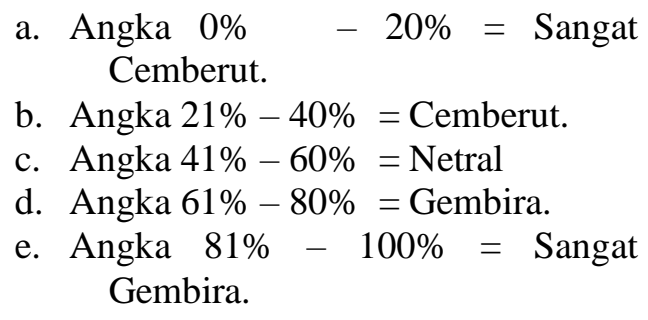

Setelah diketahui kriteria interpretasi skor berdasarkan interval, maka dlakukan penilaian interpretasi skor perhitungan responden terhadap kepuasan pegawai dalam menyelesaikan pekerjaan adalah hasil nilai yang dihitung dengan menggunakan rumus indeks nilai dalam persentase. Menurut (Abduh, 2015), adapun rumus indeks nilai dalam persentase adalah sebagai berikut, yaitu:

$$
\text { Indeks Nilai }=\frac{\text { Total Skor }}{\mathrm{Y}} \times 100 \%
$$

Setelah diketahui indeks nilai berdasarkan metode interpretasi nilai tersebut, maka dapat ditentukan tingkat kepuasan kerja pegawai dengan cara sebagai berikut ini, yaitu:

$\begin{gathered}\text { Tingkat Kepuasan Kerja }= \\ 64 \%+70 \%+61 \%+69 \%\end{gathered}=66 \%$

Berdasarkan hasil perhitungan dari masing-masing aspek kepuasan kerja pegawai yang diperoleh dari indeks nilai, bahwa tingkat kepuasan kerja pegawai di MTS Ma'arif Cipakem adalah sebesar 66\%. yang berarti termasuk dalam kriteria Gembira. Oleh karena itu, dapat disimpulkan bahwa pegawai tersebut memperoleh rasa gembira dalam melakukan aktivitas kerjanya di ruang kerja MTS Ma'arif Cipakem.

\section{V.KESIMPULAN}

Berdasarkan pembahasan tentang analisis biomekanika kerja dan lingkungan fisik kerja terhadap kepuasan kerja pegawai diatas, maka dapat disimpulkan sebagai berikut:

1. Dari hasil analisa postur kerja tersebut, bahwa hasil final score metode $R E B A$ yang diperoleh dari tabel adalah 10. Berdasarkan tabel resiko REBA menunjukkan bahwa kondisi ini berada pada level risiko yang tinggi, maka perlu segera tindakan untuk memperbaiki postur kerja sehingga dapat meminimalisir gangguan musculoskeletal disorder.

2. Dari hasil analisa lingkungan kerja fisik tersebut yang terdiri dari pengukuran tingkat pencahayaan dan tingkat kebisingan ruang kerja pegawai, bahwa hasil intensitas cahaya yang diperoleh berdasarkan pengukuran pencahayaan dengan lux meter adalah 82.3 lux yang dimana nilai tersebut belum memenuhi standar yang ditetapkan oleh peraturan KEPMENKES RI. No. 1405/MENKES/SK/XI/02. Lalu, berdasarkan pengukuran kebisingan suara dengan sound level meter adalah 102.2 desibel (dB) yang dimana nilai tersebut berada pada zona dengan pelindung ear muff karena ruang kerja di MTS Ma'arif Cipakem memiliki intensitas kebisingan lebih besar dari $95 \mathrm{dBA}$ sebagaimana yang sudah diatur dalam keputusan Menteri Tenaga Kerja No. KEP/51/MEN/1999.

3. Dari hasil pengukuran kepuasan yang ditinjau dari aspek biomekanika kerja dan lingkungan kerja fisik pegawai dengan melakukan perhitungan interpretasi skor penilaian pada metode face scale berdasarkan indeks nilai, maka diperoleh tingkat kepuasan kerja pegawai adalah sebesar $66 \%$ yang berarti termasuk dalam kriteria Gembira. Oleh karena itu, dapat disimpulkan bahwa pegawai yang melakukan aktivitas pekerjaannya di ruang kerja MTS Ma'arif Cipakem memperoleh rasa gembira dalam menyelesaikan pekerjaannya. 


\section{DAFTAR PUSTAKA}

Higneet, S. 2000. Rapid Entire Body Assessment (REBA). Applied Ergonomics Vol 31 Hal 201205. Australia: Barkeley Valey Inc.

Iridiastadi, Hardianto, Ir., MSIE., Ph.D. 2013. Ergonomi Suatu Pengantar. Bandung: PT Remaja Rosda Karya

Nurfitriani, Wina. 2015.” Analisis Faktor Lingkungan Fisik Yang Mempengaruhi Kondisi Kantor”. Jurnal Skripsi. Bandung: Politeknik Negeri Bandung

Nurmianto, E. 2008. Ergonomi Konsep Dasar dan Aplikasinya. Surabaya: Guna Widya.

Sedarmayanti. 2014. Manajemen Sumber Daya Manusia Dan Produktivitas Kerja. Bandung: CV Mandar Maju.

Silvia, Dwi Eka. dkk. 2016.” Pengaruh Lingkungan Kerja Fisik dan Non Fisik Terhadap Kepuasan Kerja dan Kinerja Karyawan". Jurnal Skripsi. Malang: Universitas Brawijaya

Soewadji, Jusuf. 2012. Pengantar Metodologi Penelitian. Jakarta: Mitra Wacana

Suhardi, Bambang. dkk. 2011."Analisis Pengukuran RULA dan REBA Petugas Pengangkatan Barang di Gudang”. Jurnal Skripsi. Surakarta: Universitas Sebelas Maret

Suhardi, Bambang. dkk. 2017."Analisis Postur Kerja dengan Metode REBA untuk Mengurangi Resiko Cedera pada Operator Mesin Binding”. Jurnal Skripsi.
Surakarta: Universitas Sebelas Maret

Sunyoto, Danang, SH., SE., MM. 2013."Perilaku

Organisasional". Yogyakarta: PT Buku Seru

Sutalaksana, I. dkk. 2006. Teknik Perancangan Sistem Kerja. Bandung: ITB Bandung.

Sutanto. 2013. Proposal Penelitian. Yogyakarta: Mitra Buku

Tarwaka. 2014. Ergonomi Untuk Keselamatan, Kesehatan Kerja, Dan Produktvitas. Edisi Kedua. Surakarta: Harapan Press Surakarta.

Triningsih. 2006." Pengaruh Motivasi Kerja dan Lingkungan Kerja Terhadap Kepuasan Kerja Guru dan Karyawan". Skripsi. Semarang: Universitas Negeri Semarang

Wibowo, Mukti. dkk. 2014.” Pengaruh Lingkungan Kerja Terhadap Kepuasan Kerja Karyawan”. Jurnal Skripsi. Malang: Universitas Brawijaya

Widodo, Suparno Eko, Prof., Dr., MM. 2015." Manajemen Pengembangan Sumber Daya Manusia”. Yogyakarta: Pustaka Pelajar

Yassierli. 2013. Ergonomi Suatu Pengantar. Bandung: PT Remaja Rosda Karyal 